\title{
Afro-humanism and the challenges for journalism education
}

\author{
Joe Thloloe
}

Please allow me to start with a disclaimer: this is not going to be an academic paper but it will rather be a report from the coalface. It comes from my experiences as a journalist and as an avid consumer of news.

I must also say upfront that my views could easily be jaundiced because, as the Press Ombudsman, I have to wade through what readers regard as bad journalism. Of course, I do temper my views by remembering that only a tiny percentage of the millions of words that are published daily in this country land on my desk, which means the bulk of the journalism is not in breach of the Press Code. However, the more I read newspapers and magazines, the more I listen to radio and the more I view our television the more dissatisfied I feel. There is a yearning inside me that our media is not satisfying. I suspect you too might have that hole waiting to be filled.

This $30^{\text {th }}$ anniversary dawns at an interesting juncture in our history. It comes when a person's worth is increasingly measured by the size of their bank balance, the price of the suit they wear or of the car they drive. We are fast losing the sense of community as each one of us claws his or her way to the top of the ladder.

The anniversary also dawns as the media in this country are reporting on two historical stories: the ousting of President Thabo Mbeki and its aftermath as well as that of the worst crisis in our lifetime in financial markets.

I've read, heard and seen stories on the road to Polokwane, where Mbeki was rejected by the ANC. I have read, heard and seen stories on the aftermath - his recall, the election of a new president to hold office for a few months, the no-holds-barred battle for the soul of the party. I am still to understand what all this means for me, for my 89-year-old mother, or for the millions who went to the polls in 2004. Are the poor and the weak just pawns in a war they can never understand?

The media were quick to repeat the reassurances from the new leadership of the country, that there will be no changes to the country's economic policies. The questions of the elite were top of the agenda for the ANC and journalists.

The journalists are not asking the hard questions. They are mere stenographers recording events as they happen.

No journalist has been able to take me into Mbeki's mind and plans for the future, no journalist has been able to take me into the heart of the Jacob Zuma camp nor has any journalist been able to take me into the Terror Lekota camp.

The same is true of the story of the financial markets. I read and try to understand. I fail. The 
journalists are recording the yo-yo movements of the stock markets and I am mesmerised by the deadly snake that is about to dart at me.

The South African Press Code states: 'The primary purpose of gathering and distributing news and opinion is to serve society by informing citizens and enabling them to make informed judgments on the issues of the time'.

In the examples I have given, the stenographers have induced anxiety, even panic, among the citizens and have not brought us understanding.

I am grateful to my friend and Canadian journalism trainer Tim Knight for reminding me that we as journalists are tellers of morality tales, of stories that should bring understanding to our readers, listeners, or viewers. To me this means an understanding of our fellow men, our communities, our country and our world. It implies an understanding of complexity.

The challenge, then, to journalism trainers and educators is to produce graduates who can tell these morality tales. The graduates have to understand the world around them before they can tell us about our fellow men, our communities, our country and our world. They will have to have the skills and, more importantly, the values to tell these stories. Values bring me to the subject of Afrohumanism.

Again allow me to divert a little and touch on business and affirmative action. In this country, after 1994, business realised that the world around it had changed or it was forced by legislation to accept that it had changed and effort was put into recruiting blacks and women into senior management positions. The men in grey suits interviewed black and female applicants for the positions and they sought out men and women who dressed like them, carried themselves like them and spoke like them - they sought their female and black male clones.

The new recruits into management had been educated in the same schools as the old managers and spoke the same impeccable English or Afrikaans. The new managers came into the hard world of the boardroom and became just as hard in order to succeed.

Nothing had changed in the boardrooms because when the new managers entered the premises of their new companies, they left the colour from the black townships and the gentle touch of the woman at the entrance and put on the grey and the hardness of their new jobs. They left the metaphors from the townships and from the woman's world at the door, instead of bringing them in to enrich the discussions in the boardroom.

Nothing changed in that boardroom. Business could have been so much richer if the old management had employed whole people with new perspectives on the world and business. Initially the new manager became schizophrenic, one personality at work and another with his friends and family after hours.

Fourteen years down the line the new manager has now moved out of the townships and lives and plays with the old managers in the suburbs of our cities. When he occasionally goes to visit his mother in Soweto, he speaks Setswana with an English accent and gropes for words because he is no longer fluent in his native tongue.

Journalism is just as guilty.

We have entered the grey and hard world of Western civilisation and journalism and we are now 
shy to talk about ubuntu or botho. I'm pretty certain that throughout our continent you will find a local word for the concept. The only acknowledgement we make to the concept in our Eurocentric journalism is to talk about Afro-humanism.

Ubuntu translated into English means 'human-ness': the state of being human. It comes with inbuilt connotations: Motho ke motho ka batho, in Sesotho, or umuntu ngumuntu ngabantu, in Zulu - a person is a person because of others, the community comes first or think of others before you think of yourself. A whole world-view is built around this concept.

When you translate ubuntu to Afro-humanism, you box it off - it is African; it is an African view of humanism; it relates to Africans or Africa only. The concept and philosophy is in fact much bigger than that: it encompasses all humanity. It is the stuff of all great literature in the world - Xhosa, Yiddish, German, English, Latin, Sioux, Urdu, you name it.

I'm sure you will all remember John Donne's immortal poem:

No man is an island, entire of itself every man is a piece of the continent, a part of the main if a clod be washed away by the sea, Europe is the less, as well as if a promontory were, as well as if a manor of thy friends or of thine own were any man's death diminishes me, because I am involved in mankind and therefore never send to know for whom the bell tolls it tolls for thee.

Donne wrote this eloquent exposition of $u b u n t u$ between the beginning of the $16^{\text {th }}$ century and the middle of the $17^{\text {th }}$.

I will not bother you with echoes of this in Ernest Hemingway's writings.

I believe ubuntu is a universal concept that should not be boxed in by boundaries and language. It is not Afro-humanism. It is an optimistic view of mankind and sums up what it means to be truly human.

Does it have currency in today's materialistic world in which young entrants see journalism as a mere stepping stone to entering other routes to amassing wealth?

Ask Thabo Mbeki about the currency of ubuntu. We watched when he was in power as he ruthlessly cut down his former comrades and created enemies. He might have been right but there was no ubuntu in his style. His was the classical tragedy of the once all-powerful ending up bewildered by his fate.

We have seen other very rich, very powerful people ending up broken and lonely in the middle of their material wealth because they forgot that no man is an island, that umuntu ngumuntu ngabantu.

There are values in this philosophy that should be inculcated into journalists from the time they start at education and training institutions - compassion, empathy, service, among them. Compassion and empathy are the mark of good journalism, just as they are the mark of great literature. If we had compassion in our journalism, we would not have publications gloating after they have exposed 
corruption. There would be a sadness that a person who once espoused great ideals and was placed in a position of responsibility had fallen to this level. We would have richer stories that made us understand.

Today many readers believe that journalists are scavengers, eager to tear up the post-1994 institutions and heroes. We are not seen as nation builders. If we showed compassion readers would be on our side, understanding our role in society. If journalists appreciated the value of serving society, the pay cheque at the end of the month would be secondary, the way it was before 1994 when journalism was a calling.

The challenge to education and training institutions now is to find a way of inculcating the values of ubuntu in their students and offering them heroes rather than those driven by greed for money and power. It will be a tough task, considering that your students are lured by the sirens around them. This is a challenge that society as a whole faces as we see the collapse of values that we have long cherished.

The skills training should be seen as secondary to the values that drive journalists.

The journalism that starts from the foundation of ubuntu would go a long way towards bringing understanding to readers of newspapers and magazines, listeners of radio and viewers of television programmes.

I wish to congratulate the Department of Journalism for its sterling work over the past 30 years. It has produced some great journalists and teachers. Unfortunately it is not time to rest: there is more work ahead.

\section{About the speaker}

Joe Thloloe is the South African Press Ombudsman 